\title{
Akinori KIDERA : Crystallographic Refinement of Protein Dynamic Structures using Normal Modes.
}

A dynamic structure refinement method for protein X-ray crystallography is presented. The Debye-Waller factor is expanded in terms of the low-frequency normal modes whose amplitudes and eigenvectors are experimentally optimized in the process of the crystallographic refinement.

Application of the method to human lysozyme showd: (1) Debye-Waller factor consists of two parts, highly anisotropic internal fluctuations and almost isotropic external terms. The former is smaller than the latter . (2) Correlation of fluctuations corresponding to the hinge-bending motion was detected.

\section{1.はじめに}

タンパク質の $\mathrm{X}$ 線結晶構造解析が低分子系と大 きく異なる点は, 精密化の観点からみると,

観測される反射の数/モデルパラメータの数 の比が十分大きくないてとにある。巨大分子であ るため構造を表現するのに必要なパラメータの数 が極めて大きくなるてとで「分母」を大きくし, 結晶の半分近くが溶媒に占められているために分 解能が限られているてとで「分子」を小さくして いる。そのような場合に最小自乗法で信頼性のあ るモデルを構築するためにはモデルの自由度を可 能な限り下げ（「分母」を小さくし）なければな らない。そのためタンパク質の構造精密化では, 平均構造については低分子系 (アミノ酸等) です でにわかっている構造の情報，つまりモデル（結 合長, 結合角等) を制約条件として導入し ${ }^{1-3)}$, 動的構造については等方的温度因子を用いゆらぎ の異方性は議論しないという単純化をしている。

タンパク質の機能に密接に関わる動的構造を議 論するには, 乙の等方的温度因子による描像では 不十分であることが第1図の比較からあわかるだ ろう。パラメータの数を増やすととなしに, X 線 回折データからもっと多くの動的構造に関する情 報（ゆらぎの異方性等）を引き出すととはできな
いのだろうか。我々は「平均構造にモデルを導入 しているように, 動的構造にもモデルを導入すれ ばパラメータの数を増やすととなしにより多くの 情報が引き出せるのではないか」と考えた。現在 ではタンパク質の動的構造は適当な力場を仮定し た種々の分子シミュレーションの方法4,5) によっ て, 平均構造が与えられればある程度の精度で予 測することが可能となっており，そこにモデルを 求めることができる。それらの中から, 最小自乗 法によって精密化されるモデルに必要な条件「で きるだけ少数の変数で記述される解析的な構造を 持つ」を満たす方法として, 我々はタンパク質の 基準振動を動的構造のモデルとして採用し, 基準 振動動的因子法を開発した ${ }^{6-8)}$ 。以下，ヒトリゾ チームを例にして基準振動を用いた精密化の方法 とそてから得られる結果について述べる。

\section{2. タンパク質の基準振動}

基準振動は低分子系と同様に, エネルギー極小 構造での二次微分行列の固有値問題を解くことに よって理論的に得られる（基準振動解析）帛。ヒ卜 リゾチームの基準振動モードの例を第 2 図に示す。 例として, 最低振動モードから順に $1,10,50$ 番 目のモードを主鎖原子の運動を表す矢印で表示し た。低分子化合物で伸縮, 変角などのモードがあ

$34.3-20$ 

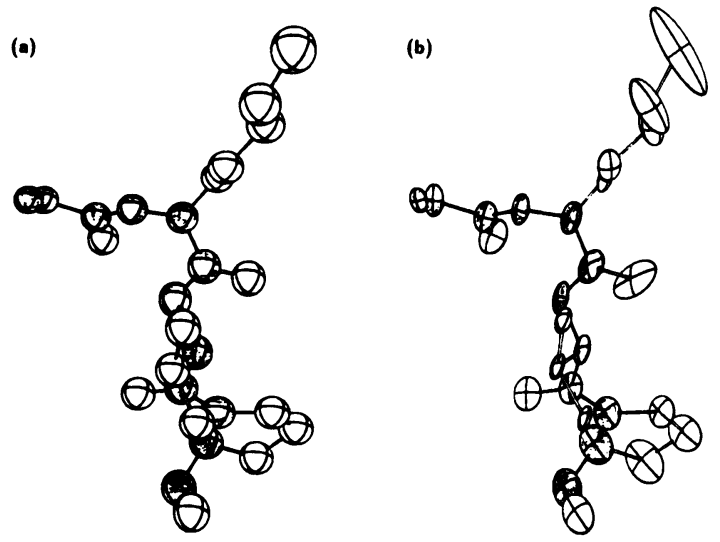

第 1 図 等方的温度因子と異方的温度因子の 描像の違い。ヒトリゾチームの部分構 造 (Gly 68-Lys 69-Thr 70-Pro 71) の熱振動楕円体を ORTEP で表示し た(主鎖原子には影をつけてある)。 (a) 通常の等方的温度因子による精 密化の結果（20\% probability scale)。(b) 基準振動動的因子法によ る精密化の結果。内部運動のみによ るゆらぎ(48\% probability scale)。

るように,タンパク質でも構造によって決まる特 徵的なモードがある。第 1 モードは二つのドメイ ン間の相互の動きを、第10モードは右側のドメイ ン全体の動きを、第50モードは左側のドメインの 一部に限定された動きを表している。振動数が低 いモードほど協同性が高くなっているてとがわか る。動的構造のモデルとしての基準振動の重要な 性質は,

(1) 自由度の数だけある基準振動の中で（ヒトリ ゾチームで 6000 余り), 少数 (高々数百程度) の 低振動（大きな掁幅を持つ）モードだけでタンパ ク質の運動のほとんどを記述することができる7。 9,10)。乙の性質によってパラメータの数を増やさ ずにより精密な動的構造の記述ができるわけであ る。

（2）基準振動は本質的に協同的な運動を記述する モデルである。この性質からタンパク質のゆらぎ の相関に関する情報を引き出すことができる。

\section{3. 基準振動動的因子法}

基準振動による動的構造のモデルはどのように 精密化すればよいだろうか。第 2 図に示したよう にタンパク質のゆらぎはいろいろな形のモードの 和として表現される。モードの形はある程度精密 化された平均構造があれば, そこから基準振動解

\section{fluctuations $=$}

$A_{1}$
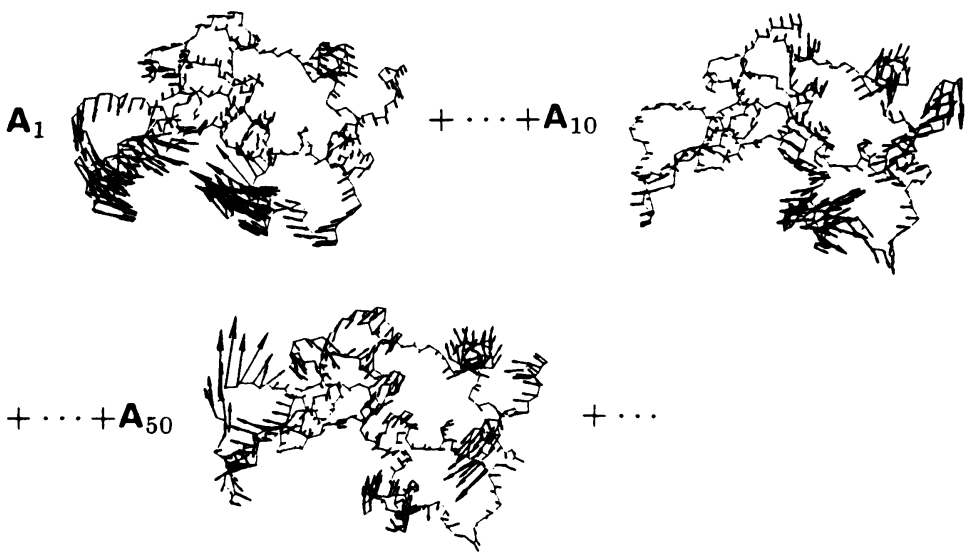

第 2 図ヒトリゾチームのゆらぎは基準振動モードの和として表現さ れる。最低振動モードから順に $1 ， 10 ， 50$ 番目のモードを主 鎖原子の運動を表す矢印で表示した。基準振動動的因子法で モードの振幅 $A_{m}$ を変数として実験データに合うゆらぎを捜す。 
析によって前もって計算しておくてとができる。 したがって, 動的構造の精密化は各モードの寄与 （第 2 図の振幅 $\mathrm{A}_{\mathrm{m}}$ ）を少しずつ変えて実験データ に最あ良く合うように最適化するてとによって行 うことができる。モードの形は理論的に予想され たあのを用い，それらの全体に対する寄与の割合 を変えて実験の電子密度分布に合わせようという 考え方である。

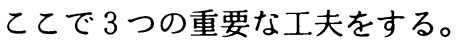

(1) 前節で述べたように用いるモードを少数の （高々数百）の低振動モードに限ることでパラメ 一タの数を抑える。

(2) 第 2 図で示した内部運動のモードだけではな く並進, 回転などの外部運動のモード（TLS モデ ル ${ }^{11)}$ )を同時に用いることで内部運動モードで表 現されない寄与, 例えばタンパク質全体の剛直な 全体運動, 格子の乱れ, 散漫散乱などを吸収する。 (3) モードの振幅（分散）だけでなくモード間の 相関（共分散）を考慮する。乙れによって振幅だ けでなくモードの形（第 2 図に示した矢印の大き さと方向）自体を精密化するてとができる。

式の形でてれらの事を具体的に示しておてう。 動的因子を基準振動で展開し，モデルの構造因子 $F_{\text {cal }}(\mathbf{q})$ を

$$
F_{c a l}(q)=\sum_{j} f_{j}(q) \exp \left(i q \cdot r_{j}\right) D W F_{j}
$$

と表現する。乙こで和は原子 $j$ 亿ついて行う。 $f_{j}$ は原子散乱因子, $\mathbf{r}_{\mathrm{j}}$ は原子 $\mathrm{j}$ の平均位置を表す座 標。DWF，は動的因子 (Debye-Waller 因子) で基 準振動によって,

$$
\begin{array}{r}
\mathrm{DWF}_{\mathrm{j}}=\exp \left[-\frac{1}{2} \sum_{\mathrm{k}} \mathrm{q}_{\mathrm{k}} \mathrm{q}_{1} \sum_{\mathrm{m} \mathrm{n}} \phi_{\mathrm{jkm}}\right. \\
\left.\phi_{\mathrm{j} 1 \mathrm{~m}} \sigma_{\mathrm{mn}}\right]
\end{array}
$$

$\mathrm{q}_{\mathrm{k}}$ は逆格子スペクトル q の要素, $\phi_{\mathrm{j} \mathrm{km}}$ は基準振 動 m（内部運動と外部運動のモードを含む）の固 有ベクトルの要素 (ベクトル $\left(\phi_{\mathrm{j} 1 \mathrm{~m}}, \phi_{\mathrm{j} 2 \mathrm{~m}}, \phi_{\mathrm{j} 3 \mathrm{~m}}\right)$ が第 2 図の矢印を表す)。 $\sigma_{\mathrm{mn}}$ は基準振動モード の分散共分散で振幅と相関の程度を表す。通常の 等方的温度因子に上る動的因子

$$
\mathrm{DWF}_{\mathrm{j}}=\exp \left[-\mathrm{B}_{\mathrm{j}} \mathrm{q}^{2} / 16 \pi^{2}\right]
$$

と比較すると 2 式のゆらぎの表現が, 異方的, 協 同的であることがわかる。 $\mathrm{F}_{\mathrm{ca} 1}$ の精密化での変数 は座標値 $\mathbf{r}_{\mathrm{j}}$ とモードの共分散 $\sigma_{\mathrm{mn}}$ である。 
(a)
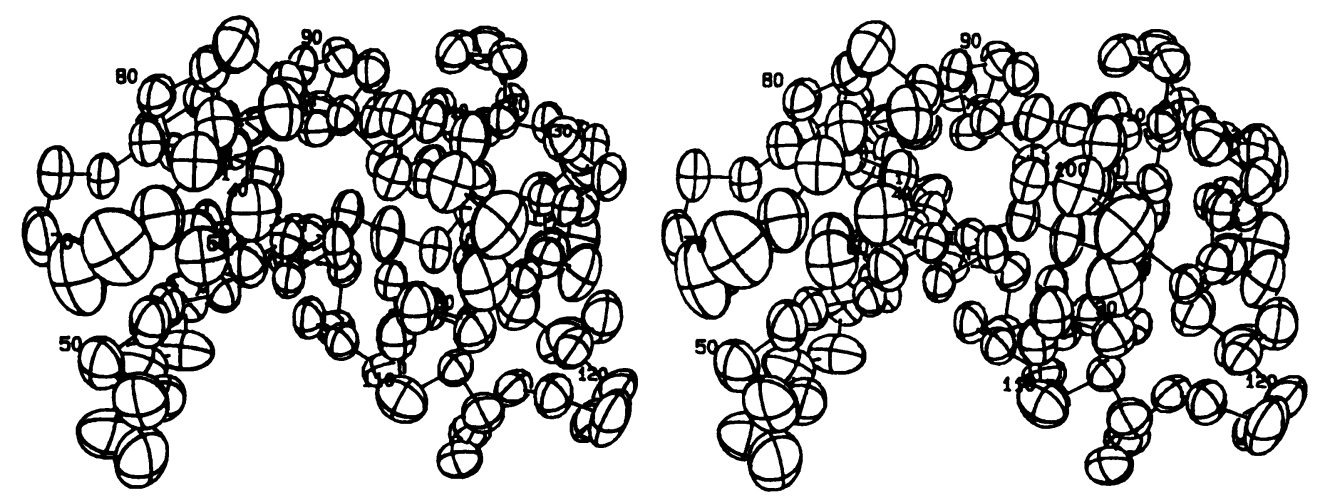

(b)
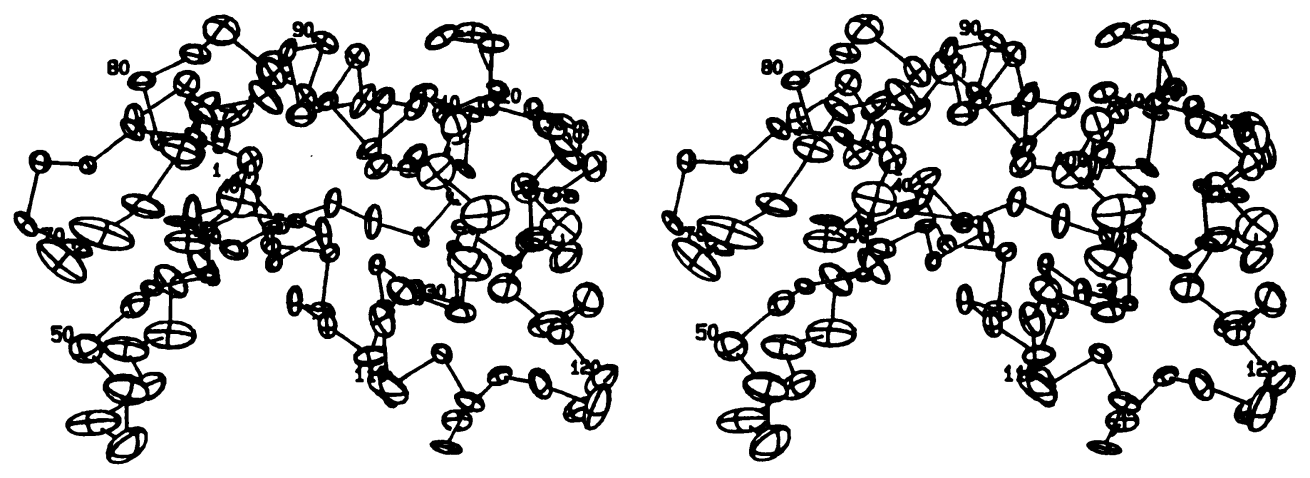

第 4 図 ヒトリゾチームの $\alpha$ 炭素の熱振動惰円体をORTEPによって表示した (90\% probability scale $)^{8)}$

(a) みかけ (内部運動+外部運動) のゆらぎ。(b)内部運動によるゆらぎ。

第 1 表 ヒトリゾチームの精密化

\begin{tabular}{|c|c|}
\hline \multicolumn{2}{|c|}{ X線結晶回折テータ } \\
\hline $\begin{array}{l}\text { 結晶形 } \\
\text { 分解能 }\end{array}$ & $\begin{array}{l}\mathrm{P} 2{ }_{1} 2_{1} 2_{1}\left(56.50 \times 60.89 \times 33.83 \AA^{3}\right) \\
5-1.8 \AA \text { (独立な反射 } 10179)\end{array}$ \\
\hline \multicolumn{2}{|l|}{ 檋造のモテル } \\
\hline 原子数 & $1029+115$ (溶媒分子) \\
\hline 内部運動モード & $\begin{array}{l}\text { 100個の低振動モードーそのうち43個モド間の相関を考慮する } \\
\text { の最低振動モー } \\
\text { (自由度 1003) }\end{array}$ \\
\hline 外部運動モード & TLS モデル（自由度 20） \\
\hline \multicolumn{2}{|l|}{ 精密化の桔果 } \\
\hline R因子 & $15.2 \%$ \\
\hline 構造の標準値 & 結合長 $0.016 \AA$ \\
\hline からのずれ & 結合角 $2.1 \mathrm{deg}$ \\
\hline
\end{tabular}

プログラムは高度にベクトル化されており（スカ ラ演算の約27倍の計算速度), スーパーコンピュ 一タで高速に計算をすることが可能である。第 1 表の系で 1 回の関数値と微分値を計算するための CPU time は約15秒 (FACOM VP2600) である。

\section{5. ヒトリゾチームへの適用}

ヒトリゾチーム結晶の X線回折データを基準振 動動的因子法で第 3 図のフローチャートに従って 精密化を行った（第 1 表）。モデルに含まれるパ ラメータの数は通常の等方的温度因子によるモデ ルとほぼ同じ数になるように選んである。結果を ORTEPによって $\alpha$ 炭素を第 4 図に側鎖を含めた 


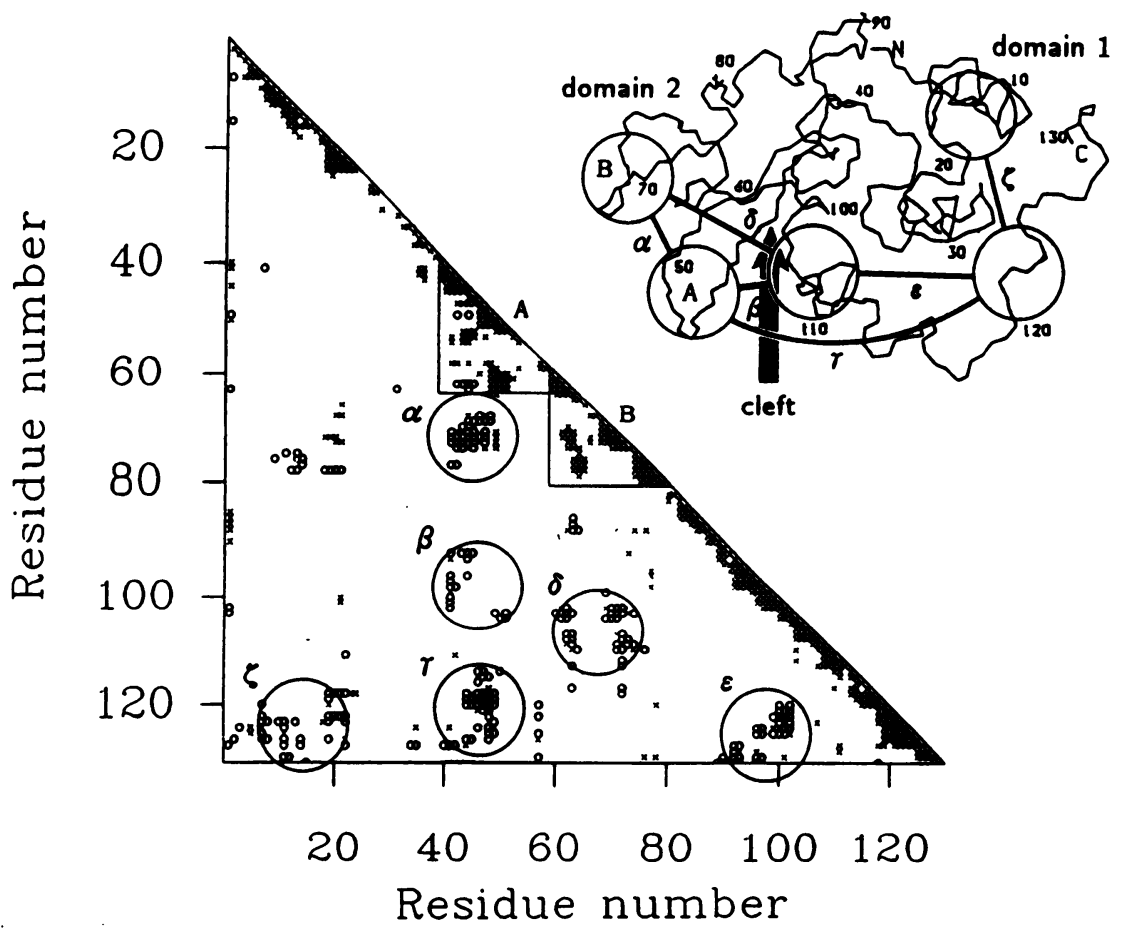

第 5 図 ヒトリゾチームの $\alpha$ 炭素間のゆらぎの相関 $\left\langle\Delta \mathbf{r}_{\mathbf{i}} \cdot \Delta \mathbf{r}_{\mathbf{j}}\right\rangle_{0} \mathrm{x}$ は強い正 の相関を。は強い負の相関を表す。対応する構造上の位置を右上の 図で示した。リゾチームは図の右側の第一ドメイン $(1-39,90-$ 130 残基）と左側の第二ドメイン $(40-89$ 残基) がクレフトを形成 する構造を持っている。図中のゆらぎの相関 $\beta \gamma \delta$ がクレフトをは さむ hinge-bending 運動に対応している ${ }^{8)}$ 。

部分構造を第 1 図(b) に示す。乙れからわかるこ とは,

(1) 外部運動モードを含めた見かけのゆらぎ（第 4 図(a)）の異方性は必ずしあ大きくない（熱振 動楕円体の軸比にして平均 1.3$)$ 。そのため等方的 温度因子による精密化の結果との座標値のずれは ほとんどなかった（変位はほとんどの原子で0.1 Å以下であった)。

(2) しかし，そてからタンパク質の本来のゆらぎ を表現する内部運動モードを取り出すと（第4 図 (b))，その大きさは温度因子のスケールで半分 以下（5.3/12.9）になり異方性は極めて大きくな る(軸比が平均 1.8 )。タンパク質のゆらぎは外部 運動で認織される奇与によって覆いかくされてお り, 内部運動モードを取り出してはじめて正しく 認識ずることができることがわかる。 （3）部分構造の内部運動をみると（第1図(b)) Lys 69 の側鎖が首振り運動をし, Pro71の側鎖が 主鎖原子と同じ方向にゆらいでいる局所的なゆら ぎの様子がみられる。

基準振動を用いることのあう一つの利点は, ゆ らぎがどのように相関しているかを精密化された 基準振動の内捜として推定できることにある ${ }^{7}{ }^{15)}$ 。 第 5 図に $\alpha$ 炭素のゆらぎの相関を表す $\left\langle\Delta \mathbf{r}_{\mathbf{i}} \cdot \Delta \mathbf{r}_{\mathbf{j}}\right\rangle$ を示す。対角線に近い部分の相関は共有結合で近 接している原子間の相関を表し, 特にループ A, $\mathrm{B}$ が剛直体としてふるまっているてとがわかる。 二つのドメイン間 $(\beta, \gamma, \delta)$ に負の相関が見ら れる。乙れはクレフト部分をはさみこむ hingebending 運動に対応している。さらにドメイン内 の $\alpha, \varepsilon, \zeta$ 部分にあ負の相関が見られる。 


\section{6. おわりに}

タンパク質の $\mathrm{X}$ 線結晶構造解析から得られる動 的構造は, その解析の困難さから必ずしも積極的 に議論されてきたとは言い難い。上に述べた解析 法がそれらの問題を解消し, タンパク質の機能に 結びついた動的構造の議論がより多くなされるよ うになることを期待する。

この研究は京都大学理学部郷信広教授, 蛋白工 学研究所松島正明氏, 東京工業大学伊中浩治氏之 共同で行われた。ここに深謝する。

\section{文献}

1) W.A.Hendrickson: Method Enzymol. 115, 252 (1985).

2) J.L.Sussman: Method Enzymol. 115, 271 (1985).

3) A.Jack and M.Levitt: Acta Cryst. A34, 931 (1978).

4) J.A.McCammon and S.C.Harvey: Dynamics of proteins and nucleic acids, Cambridge University Press (1987).
5) C.L.Brooks, M.Karplus and B.M.Pettitt: Proteins: A Theoretical Perspective of Dynamics, Structure, and Thermodynamics, John Wiley \& Sons (1988).

6) A.Kidera and N.Go: Proc. Natl. Acad. Sci., U.S.A. 87,3718 (1990).

7) A.Kidera and N.Go: J.Mol.Biol. 225, in press (1992).

8) A.Kidera, K.Inaka, M.Matsushima and N.Go: J.Mol.Biol. 225, in press (1992).

9) T.Nishikawa and N.Go: Proteins 2, 308 (1987).

10) N.Go: Biophys. Chem. 35, 105 (1990).

11) V.Schomaker and K.N.Trueblood: Acta Cryst. B24, 63 (1963).

12) P.K.Weiner and P.A.Kollman: J. Comput. Chem. 2, 287 (1981).

13) H.Wako and N.Go: J. Comput. Chem. 8, 625 (1987).

14) K.Morikami, T.Nakai, A.Kidera, M.Saito and H. Nakamura: Computer \& Chem. in press (1992).

15) A.Kidera K.Inaka, M.Matsushima and N.Go: Biopolymers, 32,315 (1992). 